\title{
Priorities and scientific achievements in branch of animal husbandry of South of Ukraine
}

\author{
Vdovychenko Yu. ${ }^{1}$, lovenko V. ${ }^{2}$, Zharuk L. ${ }^{3}$, Zharuk P. ${ }^{4}$, Yakovchuk V. ${ }^{5}$, Dudok A. ${ }^{6}$, Dudka $0 .{ }^{7}$, \\ Fursa N. ${ }^{8}$ \\ "Ascania Nova» Institute of Animal Breeding in the Steppe Regions named after M.F. Ivanov- \\ National Scientific Selection-Genetics Center for Sheep Breeding. e-mail: ${ }^{1} y u r i y \_v d o v y c h e n k o @ u k r . n e t$,

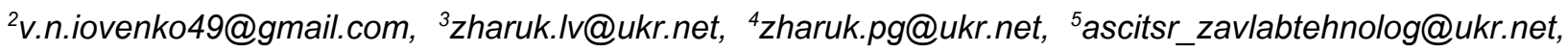 \\ ${ }^{6}$ ardudoc@ukr.net, 7 dudka-olena@ukr.net, ${ }^{8}$ ascitsr_mysnoe@ukr.net
}

The purpose. To generalize results of reaching of scientists of IAHSZ "Askania-Nova" in branch of animal husbandry and to light problems and prospects of scientific researches in modern economic and nature-climatic conditions in Ukraine. Methods. Selection-genetic, immune-genetic, genetic-biochemical, population-genetic, technological, biometric. Results. Results are given of work of scientists of the Institute in selection, genetics and technology of animal husbandry of South region of Ukraine, as well as problem and perspectives of branch in modern economic and nature-climatic conditions. Series of highly productive gene pools of animals in sheep breeding, cattle husbandry and swine breeding which make the basis of genetic resources in region, and for sheep breeding - in the state as a whole, had been created during existence of the institute. Modern selection-genetic methods and methodology of development of existing and creation of new breeds, types and lines of animals, technologies of production and processing of products of sheep breeding, modern biogeotechnology of duplicating valuable genotypes are developed. Use of scientific developments provides high level of productivity of branch and short terms of their pay-back. Conclusions. Scientists of IAHSZ "Askania-Nova" (centre of science selection in the south of Ukraine) developed a series of selection-genetic, technological, biotechnological methods, techniques, system of assessment and development of genotypes of animals. That allowed creating of domestic highly productive, adapted to extreme natural-climatic conditions of the region gene pools of cattle (milk and meat directions of productivity), sheep and pigs. Today these animals make the basis of genetic resources of animal husbandry of the state. Their use promotes recovery of separate branches, in particular sheep breeding, and others - to increase production of highprotein food stuffs, including produce of organic direction.

Key words: sheep, pigs, cattle, selection, genetics, technology, productivity.

https://doi.org/10.31073/agrovisnyk201811-14

The main scientific research institution that provides scientific support to the livestock sector in the south of Ukraine is the "Ascania Nova" Institute of Animal Breeding in the Steppe Regions. Since the founding (1931), the pleiad of world-renowned scientists had worked in the Institute, including M. F. Ivanov, Yu. O. Filipchenko, M. M. Zavadovsky, O. O. Browner, O. S. Serebrovsky, M. T. Balashov and many others. They have developed and published a number of important scientific papers on zoology, embryology, and genetics, evolutionary theory, which have made a significant contribution to the practice of biological and breeding research. A number of theoretical positions of the genetic basis of selection have been developed. An open phenomenon of feedback as a principle underlying the development of an organism and the interaction of its systems. This discovery has begun the development of bio-cybernetics in world science. The domestic endocrinology was created and the method of hormonal stimulation of sheep's prolificacy breeding was developed. The basis of zoological Zootechnics was formulated, a clear classification of the conditions of the breeds' formation process was developed in the light of the historical evolutionary theory.

The idea of gene separation was proposed, genogeography was based, and the basis of large-scale breeding in livestock was presented. A deep analysis of the data on the phenogenic and genetic resources of hybridization for different species of animals had been made. The global problem of 
preservation the rare and endangered animal breeds' gene pool was foreseen, the determination of "signaling genes" methods and the pests' control of agricultural plants were developed.

The scientists of the Institute have deepened the theoretical positions on agricultural animals' linear breeding. The advanced methods of breeding pigs using the breeds' combination ability, lines and the creation of paratypic conditions for the manifestation of their potential hereditary features have been developed.

The problems of acclimatization and breeding the imported Duroc pig breed have been solved, and the method of using "geographic" heterosis in the intra-breed matings has been developed.

The original method of studying the skin histological structure features of the farm animals has been developed.

Many methodological questions have been solved for optimizing animals' rations by composition of macro- and microelements in feeds grown in the south of Ukraine.

The intra-breed matings systems and remote hybridization have been developed in order to form perspective genotypes of cattle beef productivity direction; the system of feed production for farm animals in the south of Ukraine and worked out certain agro technical methods of combating drought and wind erosion of soils in the southern region of Ukraine and methods of field protection forestry; a number of fundamental theoretical questions on the problems of remote hybridization of ungulate mammals and poultry; methodology for increasing the accuracy of the genotype estimation. animals to achieve guaranteed heterosis in pig breeding.

The scientists of the institute have, such modern achievements in the breeding process: a Tavrian Type of Ascanian Fine-Fleece breed of sheep was created in sheep breeding; Ascanian Meat-and-Wool breed of sheep with crossbred wool, which includes five intra-breed types; Ascanian Karakul breed with three intra-breed types and 10 genealogical lines.

In the cattle breeding were created: the Ukrainian Red Dairy breed, which has such intrabreed types - Holstein and with high milk-fat content, they include 5 zonal types and 13 lines; the Southern type of Ukrainian Black-and-White breed; the Southern Beef Cattle with two intra-breed types, six lines and 39 families; also we have the gene pool's herds of Grey Ukrainian and Red Steppe breeds.

In pig breeding: there is the Ascanian Meat type of Ukrainian meat breed of pigs.

Integrated modern technology for the selection farm animals based on molecular genetic markers has been created, the introduction of which ensures the growth of herds productivity and the efficiency of the breeding process.

New areas of research on biotechnology and cellular engineering have been launched. The methods of sheep embryo transplantation and embryoclonination, sheep "In Vitro" were developed, and the technology of cryopreservation of semen of sheep breeders was improved.

To create an information environment that provides for efficient breeding work, a system for controlling the breeding process in sheep breeding by means of information technologies with the use of an integrated system for collecting, storing and processing selection genetic information has been developed.

The purpose of researches - to summarize the IABSR "Ascania-Nova" scientists' work results in the field of animal breeding and also the determination of problems and prospects for scientific researches under the current economic and natural climatic conditions that have developed in the state today.

The research methodology. Methodological basis of scientific researches were the modern selection genetic methods of the improvement of and breeding the animals' new gene pools; the immunogenetic, genetic-biochemical, population-genetic - for monitoring and genetic evaluation of animal populations; at the working out the technologies of production and processing of sheep breeding products was used the technological methods.

\section{The results of researches.}

A scientific search for increasing the productivity of existing and introducing new gene pools of farm animals in the south of Ukraine comes from the achievements of academician M. F. Ivanov, who created the scientifically-based method for the discovery of new genetic formations in Askania Nova, with the use 
of which a number of breeds, types and lines of animals were created. And today, this technique is the main tool of scientists-breeders activity.

\section{The sheep's genetic pools of Ascanian breeding}

The Ascanian Fine-Fleece breed. In 1925, in Askania-Nova, academician M. F. Ivanov began work on the creation of a new breed of fine-fleece sheep. Because of the many years fruitful work, a breed was created, which was called Ascanian Rambouillet sheep. The average clip of unwashed wool at the time of the testing of the breed was $5.8 \mathrm{~kg}$; the yield of pure fiber was $40 \%$, clip of washed wool $-2.32 \mathrm{~kg}$. According to the clip of yield and quality of the wool, the Askanian herd at that time ranked the first among all merino herds.

The growing requirements for the quality of Merino wool and wool productivity set additional requirements for the improvement of Ascanian sheep breeds and the creation of tribal herds with a high wool clip of pure fiber and improved the wool qualities. In this regard, the scientists of the Askania Nova Institute, using the intra-breed method, began a work on the creation of a new type of Ascanian FineFleece sheep with the involvement of the Australian merino gene pool.

The use of these breeds has given positive results. The wool clip of pure wool in herds of breeding farms increased by $0.87-1.2 \mathrm{~kg}$ and amounted to $3.3-3.6 \mathrm{~kg}$ on average, the yield of pure fiber, respectively, was $10-12 \%$ and $50-55 \%$, the length of the wool increased by $1,5-2.0 \mathrm{~cm}$, qualitative characteristics of wool have improved.

Ascanian Meat-and-Wool breed with crossbred wool. The breed consists of two intrabreed types Ascanian crossbred and Ascanian Black-Heads.

Ascanian crossbreds. The basis of the method of their breeding is gradual selection based on the use of the domestic and world gene pool by the method of complex reproductive crossbreeding between the genotypes contrasting with the phenotype of the half-blood Lincoln-Ascanian rams with Lincoln-Tsigai sheep breeds, mainly F2-F5. In the next stage, further breeding "inside itself" of the three-breeds' hybrids of the desired type was carried out: half-blood for Lincoln and quarter-blood by Ascanian fine-fleece and Tsigai sheep breeds.

Ascanian crossbreds are large, precocious animals with high meat, milk and wool productivity. The average live weight of Ascanian hybrid's rams is $124 \mathrm{~kg}$, the length of wool is $18.7 \mathrm{~cm}$, and the clip of pure wool is $9.3 \mathrm{~kg}$, with a yield of $72 \%$; ewes, respectively, $77 \mathrm{~kg}, 15.7 \mathrm{~cm}, 5.6 \mathrm{~kg}$ and $71 \%$. The records of clean wool clip in Ascanian crossbred rams - $12.8 \mathrm{~kg}$, at the age of one year - 10.3; the ewes - 8.8, gimmers $-8.9 \mathrm{~kg}$ with a coefficient of woolness, respectively, 102, 115, 95 and $119 \mathrm{~g} / \mathrm{kg}$.

The ewes are characterized by productive longevity with an average prolificacy of $145-148 \%$, maximum at the age of seven - $183.3 \%$. The dairy capacity of ewes for 120 days of lactation is $201.3 \mathrm{~kg}$. Milk contains on average percentage: fat 6.26; protein 5.97; milk sugar 5.1; ash 0.94.

The Ascanian Black-Head sheep are bred by way of step-by-step synthetic breeding with complex reproductive crossbreeding of sheep breeds of the Tsigai breed with English Suffolk and Oxfordown, "blood pouring" of Ascanian crossbreds and the special selection of pairs with the use of inbreeding.

Ascanian Black-Head sheep are strong constitution, precocious with perfectly meat forms. A characteristic feature of sheep of intensive type is a large quantity (the average live weight of ram-sires is $122-136.8 \mathrm{~kg}$, rams at the age of one year - 72-83, ewes - 75-80 and gimmers - 60-66 kg). Meanwhile, the average prolificacy is $145 \%$ (maximum 183), the amount of milk for 120 days of lactation is $201.2 \mathrm{~kg}$ (maximum $339.7 \mathrm{~kg}$ ), and the production of meat per ewe is $78 \mathrm{~kg}$. The ram-sires length of the wool is from - 16-18 cm, ewes -13,7-14,4, young animals at the age of 14 months $19-21 \mathrm{~cm}$. Sheep have a high coefficient of woolness $(60-82 \mathrm{~g} / \mathrm{kg}$ ) and high clip of pure fiber: an average of $4.5-5.3 \mathrm{~kg}$ (in ram-sires 7.6-8.12, ewes - 4.5-5.0). The wool is flattened, clearly winding, durable $(9.5-11.2 \mathrm{~cm}$ in length) elastic and silky with chandelier shine. Crossbred wool has a reduced tonic (for rams 37.5, ewes - 35.2 microns), high quality wool grease of light shades (the ratio of fat and salts of sweat in ram-sires is 1: 0.98).

Animals are well adapted to local conditions, are very sensitive to high levels of nutrition, effectively use nutrients of forage, and consistently transmit to their descendants their valuable features. 
Ascanian Karakul breed of sheep. In 1932 in Askania Nova, under the guidance of academician M. F. Ivanov, a research work was started on the creation of a new breed. On the basis of crossing the Karakul sheep with the Romanovs, a breed, which had the prolificacy of $150-160 \%$, and the output of premium lamb's skin was 50-60\%, was created. Since 1934, a student and follower of M.F. Ivanov, a candidate of the Agricultural Sciences I.L. Peregon, had successfully continued these studies.

This breed of sheep was approved by the order of the Ministry of Agrarian Policy of Ukraine No. 176/36 of March 18, 2009. The breeding structure of the breed is three inner-breed types: the Ascanian Karakul breed type of black color sheep, the Ascanian Karakul breed type of grey color sheep, and Bukovinian type of Karakul sheep and ten genealogical lines of black and three gray colors. Animals of the new breed are characterized by combined productivity, high adaptive capacity, strong constitution, increased reproduction performance and productivity. They have a significant advantage over pure-bred Karakul sheep. From ewes of Ascanian Karakul breed for lactation, 120-140 kg of milk are obtained - a highly nutritious food and raw material for the production of delicious soft and hard cheeses. At the slaughter of lambs at the age of 4 months, the weight of the carcass is $12-13 \mathrm{~kg}$, the slaughter output is $47-48 \%$, the output of the first grade meat $-76-77 \%$ with a meatiness coefficient $-3.2-3.3$. In animals of 9 months of age, the relevant indicators are: $18-20 \mathrm{~kg} ; 48-50 \% ; 78-80 \% ; 3.9-4.0$.

Today, the Karakul breeding requires the wide development of integration ties between industrial enterprises and sheep farms of the public and private sectors, as well as the introduction of processing of products of the Karakul sheep in places of production through the organization of processing enterprises.

Resource-saving technologies of production and processing of sheep breeding products

One of the main factors in increasing the competitiveness of sheep breeding is the introduction of new technological methods of production and processing of products in the industry [1]. For effective management of the sheep breeding based on the implementation the genetic potential of breeds and types three new technologies have been developed and introduced into production at the Institute. They are the technology of lambs' meat production; the technology of the competitive lamb and young lamb organic meat production on the basis of environmentally safe content with the use of natural fodder products to obtain products in accordance with the requirements of European standards; technology of sheep milking and milk processing using new technical means.

\section{The production technology of young lamb meat.}

Based on the system of obtaining three lambing in 2 years using three cycles and different feeding periods of lambs, as well as technological and veterinary requirements for sheep meat production [2]. This technology provides: continuous production throughout the year at certain intervals of an equal number of young lamb meat; fattening intensity at average daily increments - up to $183,7 \mathrm{~g}$; the live weight of fattened animals at 6,5 months of age $-43-45 \mathrm{~kg}$, in $8.0-$ months aged $50-54 \mathrm{~kg}$; receiving lambs before the slaughter of the first class for live weight and the first category by weight; obtaining annually per one ewe $35-40 \mathrm{~kg}$ of meat.

The technology of the production of young lamb meat, which was created based on the results of three technological cycles, provides 6.5 months the slaughter weight of $19.7-20.8 \mathrm{~kg}$, and in animals, it is 8.0 months age $-23.5-24.8 \mathrm{~kg}$. The slaughter yield of meat in animals, which are 6.5 - and $8.0-$ monthes age, was $46.1-48.5 \%$ and $46.9-50.4 \%$, respectively.

An important indicator for determining the quality of a young lamb meat is the content of intramuscular fat in the longest muscle of the back. It accurately reflects the taste, gives the meat tender consistency and improves the nutritional value. The chemical analysis showed that the lambs are 8.0-monthes old ages had $3.09-3.24 \%$ intramuscular fat, whereas animals 6.5 months age $-3.06 \%$.

The developed technology is one of the components in creating the expert potential of this product in Ukraine.

The technology of organic production of competitive lamb and young lamb meat based on environmentally safe maintain with the use of natural fodder products to obtain products in accordance with the requirements of European standards. 
The constituents of the technology are: growing the resistance lambs in the suckling period using the probiotics; the maintenance of ewes with lambs in the suckling period in the pastures created according to the requirements of organic production; the use of new feeds that are common in southern Ukraine such as Austrian Artemisia austriaca, Artemisia taurica Willd, Romance (Anthemis ruthenica); weaning the lambs at 4.0-4.5 months of age with followed by their maintenance on the pasture using concentrated feed, macro- and trace elements; keeping with the maximum number of young sheep at the age of 4.55.5 months per hectare (equivalent to $170 \mathrm{~kg} \mathrm{~N} /$ ha / year), which is 19.9 heads in accordance with the requirements of organic production; the use of concentrated feeds not more than $40 \%$ of the dry matter of a ration of 4.5 months old in the form of whole grains; the use of fattening, which does not exceed one fifth life expectancy of the animal; carrying out slaughter of animals at slaughter points in accordance with the requirements of organic production while minimizing their suffering; creation of technological and veterinary requirements for the processes of lambs growing, fattening, environmentally safe keeping.

The conducted researches have established that the technology of organic production of lamb and young lamb meat provides for obtaining up to 6.5 months of average daily gain of lambs up to $171.2 \mathrm{~g}$ and live weight up to $43.7 \mathrm{~kg}$, receiving carcasses by fattening of the first category and by weight (20, $5 \mathrm{~kg}$ ) of the first class with the contents of heavy metal carcasses ( $\mathrm{Pb}, \mathrm{Cd}, \mathrm{Mn}, \mathrm{Cu})$ in the muscle tissue that do not exceed the maximum permissible concentration. The technology meets the requirements of organic production.

The problem of widespread implementation of organic sheep breeding in Ukraine is an imperfect legislative framework regulating the principles, rules and methods of organic production [3].

In further research, the search for the most effective probiotic agents for their use in the suckling period will be continued, which will, in the first place, ensure increased resistance of the young sheep.

\section{The technology of milking dairy sheep and milk processing using the new technical means.}

A significant untapped stock of sheep breeding in market conditions is the production of sheep's milk, followed by its processing. Wide introduction of sheep milking is constrained by the labor-intensive process of milking and the lack of domestic inexpensive and reliable means of mechanization, which would significantly reduce the complexity and ensure the receipt of high-quality sheep's milk for further processing in competitive products under the conditions of collective and farm enterprises.

For the farms, the Institute developed a two-stage milking unit of linear type for sheep (patent UA No. 99802), which provides high technology, rapid formation of the reflex to the process of machine milking due to its structural features in milk production in accordance with the standards of bacterial contamination. This allows during the processing of milk to receive high-quality soft brine cheeses. In general, the advantages of production of soft brine cheeses are: efficient use of raw materials; the possibility of selling cheese without ripening or with a short maturing period; high organoleptic parameters; high nutritional and biological value; rapid turnover of investments $[4,5]$.

In addition, the technology of sheep milking and milk processing with the use of new technical means has been developed. The components of this technology are: the maintenance and feeding of dairy milking ewes; preparation of ewes for machine milking according to the technological and veterinary requirements; machine milking of ewes on a developed two-stage milking line of a linear type according to the regime requirements; monitoring of the quality of milk and its bacterial contamination; processing of milk in brine cheese using highly efficient starter cultures and developed technological equipment for forming and self-pressing of cheese mass (patent UA №86532); monitoring of the quality of brine molded cheeses (brynza); technological and veterinary requirements (regulations) on the processes of preparation of the ewes, their machine milking, processing of milk into the brine cheeses (brynza).

The developed technology provides: the unification of increasing the process of milking process; the productivity of the two-stage milking installation of linear type is up to 120 animal / hour; a significant acceleration of the period of training of ewes to the machine milking, they come into the machine independently in 2-3 days; we receive milk, which indicators of bacterial contamination are in accordance with the current normative documents; production of brine molded cheeses (brynza) in accordance with the requirements of DSTU 7065: 2009. 


\section{Development of the dairy cattle breeding south of Ukraine}

For the development of the dairy cattle breeding in the south of Ukraine, the Ascania Nova Scientific Research Institute has created a highly productive, adapted to the extreme conditions of the region, a Ukrainian Red Dairy breed, which is a numerical livestock population, distributed by the range, competitive in terms of economically useful features, branched out, generally structured, phenotypically differentiated, sufficiently consolidated in intra-breed breeding groups (types, lines, families, etc.), specialized dairy breed with sufficient reserves for selection improvement as a means of pure breeding, and with the further involvement of the best world genetic material of improving breeds based on the principle of an open system.

The cows of the Ukrainian Red breed pedigree part are dominated by the estimated average productivity of the population of Red Dairy Cattle in Ukraine at $694-765 \mathrm{~kg}$ for a relatively high fat content of milk.

The average yield of the best lactation in the breed is $5755 \mathrm{~kg}$ of milk with a fat content of $3.84 \%$, $221.5 \mathrm{~kg}$ of milk fat, $3.24 \%$ of protein, including intrabreed species: Holstein $-5812 \mathrm{~kg}$ of milk with a fat content of $3.84 \%, 223,2 \mathrm{~kg}$ of milk fat, $3.24 \%$ protein and fat and milk $-5528 \mathrm{~kg}$ of milk with a fat content of $3.88 \%, 214.8 \mathrm{~kg}$ of milk fat, $3.23 \%$ of protein.

The composition of the Red Dairy breed consists of two intrabreed types: with high milk-fat content and Holstein.

Reproductive crossbreeding of the Red Steppe breed with the Angler and the Red Danish breeds bred the type with high milk-fat content. During 305 days of the first lactation, an average of $4,731 \mathrm{~kg}$ of milk with a fat content of $4,0 \%$ was obtained per each cow, and for the same period of full-age lactation, respectively, $5656 \mathrm{~kg}$ with a fat content of $4,06 \%$. The protein content of milk was about $3.4 \%$. The dairy type of exteriors, high resistance to high temperature of the environment, satisfactory reproductive ability and slaughter quality characterize animals of this type, which ensure the high efficiency of their use under the extreme conditions of the hot climate of the south and east of Ukraine.

The Holstein type was bred from the reproduction of Red Steppe Cattle with lack-and-White Holstein in farms in the southern regions of Ukraine. Animals of this type are characterized by high intensity of growth, milk type of exteriors, high milk yield (over $6000 \mathrm{~kg}$ milk per lactation), high fat content in milk (3.7-3.9\%), high reproductive capacity (0.970), satisfactory heat resistance and slaughter quality.

In the breed, in addition to the two intra-breed types of with high milk fat content and Holstein, five zonal breeding types were formed: central, eastern, western, Tavrian and Crimean.

The Ukrainian Red Dairy breed is breeding in nine southern and eastern regions, where its share in the total livestock population is between 20 and 97 per cent.

The basic farms for the breeding of the Ukrainian Red Dairy breed are breeding farms and, in part, the best private farms in the southern and eastern regions.

The Tavrian Zonal breeding Type has the largest share area: it includes Kherson, Zaporozhye and Mykolaiv regions, where these animals are bred in 27 basic farms (Shirokoie, Partizan, Zoria, Kolos, Semenovskoie, Kirova and others).

Scientists of the Institute created the southern intrabreed type of Ukrainian Black-and-White Dairy breed by crossing the breeding livestock of Red Steppe breed with bull sires of the Holstein breed. A significant proportion of livestock was obtained from Black-and-White breed cows imported from Western Europe and the CIS.

The average dairy productivity for the first-born cows is $5251 \mathrm{~kg}$, for the second lactation - $6020 \mathrm{~kg}$, full-age cows - $6245 \mathrm{~kg}$ milk. The fat and protein content of milk is $3.72-3.97 \%$ and $3.20-3.30 \%$, respectively. Cows of the new intra-breed type exceed the milk yield of cows-analogues of the original breed by almost $2400 \mathrm{~kg}$ per lactation. They have a strong constitution, satisfactorily developed muscles, their shape of the body is inherent in dairy cattle. Their live weight is $532-596 \mathrm{~kg}$. The average measurements of these animals are: height at the withers $-132-136 \mathrm{~cm}$, depth of the breast $-72-75 \mathrm{~cm}$, breast width $-42-46 \mathrm{~cm}$, the curvature length of the body $-153-157 \mathrm{~cm}$, breast circumference $-190-195$ 
$\mathrm{cm}$. The udder has cup-shaped and bath-shaped forms. The intensity of the rapid of milking is within $1,60-1,98 \mathrm{~kg} / \mathrm{min}$.

The Southern Type animals' population is consolidated by the main breeding features and adapted to the advanced technologies of milk production. Animals of this breed are suitable for the keeping under the pasture condition.

The economic effect of using the cows of the Southern Intra-breed Type of Ukrainian Black-and-White Dairy breed per 10 thousand animals is $2,800,000 \mathrm{UAH}$.

Among the main factors hampering the development of Ukrainian Dairy cattle breeding, one should distinguish the following: reducing cows, reducing milk production, low quality milk and raw materials, and, accordingly, low prices for it, outdated technology, which, above all, leads to growth cost reduction, reduction of profitability and non-compliance of domestic norms concerning the quality of milk with modern world standards.

In order to solve the problems facing the industry, it is necessary: to legislatively provide conditions for increasing the number of cows both in agricultural enterprises and in households with the provision of assistance in providing production equipment and payment of state subsidies for the saved stock; to improve the breeding business in dairy cattle breeding, to stimulate the purchase of breeding animals by all categories of farms, which will, first of all, increase the productivity of cows; organize production and service cooperatives for milk production, family farms based on households; to raise the requirements for the quality of milk sold to dairy enterprises, and to improve the system of its control; stimulate the integration of agricultural and processing enterprises, the creation of agricultural enterprises own production capacities; stabilize the price situation on the milk market. Solving these priority tasks will help solve the problems facing the industry.

\section{Southern Beef Breed is an innovative breeding achievement in the beef cattle breeding}

In order to ensure the demand of the Ukrainian population for high quality, cheap, environmentally friendly beef, to ensure food security of the country, the domestic branch of specialized meat cattle breeding is intensively developing. Creation and use of domestic breeds of beef cattle, adapted to the local ecological and production conditions of breeding - the main factor in the efficient functioning of the industry in modern market relations.

The Southern Beef breed was purposefully created by the scientists of the IABSR "Ascania Nova" for the zone of hot dry arid Southern Steppe of Ukraine. In this work, the first time in Ukraine was applied in the breed creation process of using the gene pool of the subspecies Bos indicus. The theoretical prerequisite for the creation of a Southern Beef breed was the production of highly productive animals based on the crossing of the Red Steppe breed and the world's gene pool of the best breeds of meat (Shorthorns, Hereford, Charolaise, Santa-Gertrude, Cuban Zebu Brahman), which would combine the genotype with better qualities: adaptability to the hard climatic conditions of the zone, high productivity and reproductive capacity, resistance to diseases, effective use of coarse fodder and pasture, the constant transfer of economic and useful features to the descendant.

In the process of creating a beef breed on a hybrid basis, a team of authors has developed an innovative methodology and breeding technology. The main provisions of them were: theoretical substantiation and selection of initial breeds for interbreeding with females of aboriginal breeds, crossbreeding and hybridization schemes, determination of the desired type of animals and the target standard of the new breed, the identification of effective breeding combinations, selection systems for animal breeders and selection of parent pairs for the descendants the desired type, development of the system and criteria for the formation of the genealogical structure of the herds created.

The implementation of new methodological and breeding developments for the creation of a new breed provided the obtaining of three- and four-breed hybrids with a polyheterozygous structure of the genotype with an increased level of phenotypic variability, in which the cultivation of the "in itself" achieved a stable inheritance of productive and reproductive features by descendants and the reception of individuals with a guaranteed high level of productivity. 
The method of reproductive cross-breeding and intrabreed hybridization using a two-stage synthetic breeding for 52 years, since 1956, formed an array of highly productive Zebu hybrid Beef Cattle.

As a result, in 2008, a new breed was tested, and on September 16, 2009, it was approved by the order №26 / 03 of the Ministry of Agrarian Policy of Ukraine "On Approval of Southern Beef Breed of Cattle and Its Inner Breeding Forms". From the point of view of the methodology of creating and achieving the level of animal productivity, this innovative product has no analogues on the European continent and in Ukraine.

Today, the Zebu Southern Beef breed of cattle is common in the southern regions of Ukraine - Odesa, Kherson, Zaporozhye.

The livestock of the Southern Beef breed is 2500 heads - includes 1000 cows The level of achieved animals' productivity of the new breed corresponds to the best world cattle breeds and consists of: the live weight of bulls-pedigrees - 950-1100 kg, full-year-old cows - 550-750 kg, bulls in 18 months - 550-600 $\mathrm{kg}$, intensity of growth live weight of bulls - $1000-1200 \mathrm{~g}$ (potential $1400-1500 \mathrm{~g}$ ); slaughter output - 60,0$63,0 \%$, fertility of cows - 85-92 live calves per 100 cows, preservation of calves to 210 -day-olds - $91 \%$.

The new domestic breeding product differs from the original exterior and strong constitution, a characteristic colour.

The created Zebu breed's gene pool is characterized by a sufficient reserve of variability of the main quantitative attributes with a high level of their inheritance and repeatability: the coefficient of variation $(\mathrm{C} \vee \%)$ for the main productive parameters is within the range of $9.35-34.62 \%$, with reproductive qualities $24,05-29.3 \%$; correlation coefficient $(r)$ of productive indicators in the range of $0,352-0,850$, coefficient of inheritance (h2) - 0,347 - 0,705.

In order to maintain the stability and heterozygosity of the genotype in the breed, a complex genealogical structure has been formed that combines two intrabreed species - Tavrian and Black Sea with 7 breeding lines.

\section{The genotypes of pigs are past and present}

The development of the pig breeding industry in Ukraine is characterized by different stages, which reflect the evolution and dynamics of this process, the corresponding to developments in the development of the theory and practice of intensifying production.

In the south of Ukraine, the pig breeding industry developed in the 30's of the twentieth century, when measures were taken to improve local, non-pedigree pigs with help of pedigree pig's breeds from England.

In 1925, M.F. Ivanov set himself the task of "... deducing on the basis of local primitive and unproductive aboriginal pigs by means of hybridization with a Large English White improved breed, in which favorable adaptability to local conditions would be combined, stamina, quickness, good payment of food, high quality of bacon and meat ".

The perseverance and outstanding talent of academician M. F. Ivanov contributed to the creation of a tribal nucleus in 1932, and in 1934 a new high-productivity domestic Ukrainian Steppe White pig breed was approved by a government act [6].

Further improvement of the Ukrainian Steppe White pigs was carried out by creating new lines both on the internal and intrabreed basis.

According to the requirements of the present, breeding and breeding work with the Ukrainian Steppe White breed aims at the development of fattening and meat qualities. Therefore, in order to increase these indicators, a new meat line of the Shum was created by the method of introductory cross-breeding with boars of Large White breed (English breeding). As a result, indicators were obtained that $10-15 \%$ exceed the standard of the Ukrainian Steppe White breed due to the speed of growth, the thickness of the lard and the output of meat in the carcass.

The second domestic breed of pigs is the Ukrainian Steppe Mottley, derived by the method of M.F. Ivanov as a plan for pure breeding, was bred and crossing in the southern regions of Ukraine. Animals of this breed are characterized by high speediness, excellent meat quality and good adaptability to the 
ecological conditions of southern Ukraine. The prolificacy of sows is $10-11$ piglets; weight of the nest at the weaning $180-190 \mathrm{~kg}$, average daily increments on fattening is $700-750 \mathrm{~g}$ [7].

Today, Ukrainian Steppe White and Steppe Mottled breeds of pigs are classified as local and endangered gene pools. Therefore, in recent years, research has been aimed at developing a system for the conservation and rational use of small populations, creating a DNA polymorphism database for valuable lines and families, a sperm bank, an information and analytical database for gene pools of local and endangered breeds of pigs.

In addition, the Ascanian Type of Ukrainian Meat breed was created. Pigs of this type have white colour, tall, have a long body, a rounded, filled ham, a deep chest, a light head, slightly saggy ears, a strong constitution and high rates of development and productivity. The prolificacy of sows is 10.5-11.0 pigs per one, the weight of the nest in two months is $180-200 \mathrm{~kg}$. With intensive fattening, the young animals grow to a living weight of $100 \mathrm{~kg}$ for 165-180 days with feed costs - 3.2-3.4 fed., the yield of meat in the carcass $-60-62 \%$ at a lard thickness of 6-7 thoracic vertebrae $22-24 \mathrm{~mm}$ [8].

At present, raising the productive qualities of this type of animals, in particular, reducing the thickness of the lard and increasing the yield of meat in the carcass, is carried out using progressive methods for assessing the breeding value of the boars and sows, as well as the extension of the genealogical structure. This made it possible to create a new line of Tsent with improved meat properties based on the method of introductory crossbreeding with the Landrace breed (English breeding): the thickness of the lard over thoracic vertebrae $6-7$ is $20-22 \mathrm{~mm}$, the area of the muscular eye $-36,8 \mathrm{~cm} 2$, meat output in the carcass $-62 \%$.

\section{Genetic studies of animals}

Using polymorphism of erythrocytic antigens of blood group systems, protein loci and DNA markers, a detailed study was performed of the gene pool and genetic structure of breeds, types and lines of sheep in the southern region of Ukraine. In the study of individual genetic groups, it was established that the level of genetic variability in terms of mean heterozygosity $(\mathrm{H})$ for protein systems within individual breeds and types varies from 0.384 to 0.548 ; in blood groups - from 0,515 to 0,548 and is consistent with the results obtained in other types of farm animals. The highest index $\mathrm{H}$ is characterized by crossbred types of Ascanian selection, created by the method of complex reproductive cross-breeding. The use of crossbreeding genotypes of sheep of domestic and foreign breeding led to an increase in the genetic variability of the newly created types compared with the original parent breeds.

Studies carried out on sheep populations of different origins and trends of productivity, show a pronounced genetic originality of the structure of each genetic group. Particularly interesting in this respect is the Tsigai breed - the result of centuries-old folk selection. However, even in genealogically closely related groups of sheep (Ascanian Prolificacy Type and Karakul breed), along with similar features, there are clearly distinct individual features. For example, if the frequency of the $\mathrm{HbA}$ allele in the Karakul breed is 0.073 , then the Prolificacy Karakul is much higher $-0.278(P<0.001)$.

In addition, studies have been conducted to determine the polymorphism of QTL genes responsible for the manifestation and level of development of quantitative productive signs of sheep in different areas of productivity.

In general, the use of genetic markers of polymorphic proteins and blood enzymes, erytrocytic antigens of blood group systems and DNA markers has made it possible to compare the genetic structures of different breeds and types of sheep, to control the genetic changes that take place there. This is especially important in connection with large-scale breeding, massive involvement of rams sires, which are improvers, to increase the productivity of local breeds, and so on.

The researches and data obtained on numerical material (about 40,000 sheep) show that the breed is a phenomenon of the unique integration of various genetic systems, and breeding aimed at supporting a certain morphological complex of morphophysiological characteristics that help distinguish between animals various breeds, is accompanied by the formation of a specific species genetic structure by immunogenetic and genetic-biochemical markers.

The obtained results showed that molecular genetic markers and developed on their basis techniques and methods can be useful for solving a number of issues of sheep population genetics, such as: 
studying the relationship between ancestral species and domestic animals; analysis of the phylogeny and ways of distribution of breeds; analysis of intrabreed differences associated under the different selection conditions; objective description of intra-breed differentiation; studying the dynamics of the genetic structure in the process of improving the existing breeds and types of sheep, as well as in the formation of new breeding groups through intrabreed crossing and in analyzing the time difference between different breeds.

In zootechnical practice sheep breeding are widely used selection according to their genotype, origin and their own productivity. However, these selection methods, due to the complexity and duration of time, are not always sufficiently effective, since they relate to the need for prior assessment of the performance of the parents and the definition of their own performance. In this context, a method (patent) for predicting the level of productivity and selection of sheep at an early age is developed, which is based on determining the influence of parent's heredity on the genotype of offspring by the distribution of molecular genetic markers. It was established that the descendants, genetically more similar to their mother than with their father, predominate their peers for live weight at birth, depending on the breed at $0.43-0.51 \mathrm{~kg}$, in adulthood by $5.3-7.1 \mathrm{~kg}$, by the clip of washed wool $-0,34-0,50 \mathrm{~kg}$.

Breeding of pedigree sheep involves a high level of selection work. One of its important elements is the selection of parent pairs, which is usually based on an animal's reassessment of origin, phenology and genotype, taking into account linear affiliation and combining ability. At the same time, it is practically impossible to assess the genotype of all individuals. In addition, it should be taken into account that it is extremely difficult to obtain timely and objective information on the advantages and disadvantages of certain options for parental pairs using the usual methods used in the sheep breeding.

Applying the types and alleles of polymorphic blood systems, as genetic markers, makes it possible to more reasonably target the selection of parent pairs to obtain offspring with an elevated level of development of selection characteristics. The developed method demonstrates that the high-quality selection of parents by molecular genetic markers ( $r a=0,0-0,32$ ) positively affects the genotype of descendants. The latter, in this case, genotypes are characterized by a significantly better level of development of live weight and wool clip compared to animals from homogeneous selection ( $r a=0,65-1,0)$.

Modern methods of optimizing gene pools of herds have also been developed taking into account breeding tasks, individual estimation of genotypes of individuals for the purpose of their intensive use in breeding programs, theoretical approaches to the use of marker genes to preserve the gene pool of local and endangered species of animals. New methods of accelerated improvement of available and creation of new breeds and types based on intrabreed breeding, crossing and hybridization have been worked out. Integrated modern technology of agricultural animals breeding based on molecular genetic markers has been created, the introduction of which ensures the growth of herds productivity and efficiency of the breeding process.

In general, developed and refined methods for monitoring micro evolutionary processes in herds of sheep, assessing the level of consolidation and differentiation of populations, control of linear breeding, objective evaluation of pedigree breeding characteristics of the descendants quality, purposeful selection of sheep on the basis of determining the level of heredity influence of each individual from the parent couples on a descendant genotype, a programmed selection of parents, taking into account the degree of their genetic similarity, makes it possible to intensify the breeding process on this basis by $15-20 \%$ accelerate the rate of selection.

An important task for further research in the genetics of farm animals to intensify the breeding process is the introduction of modern DNA technologies for direct genetic analysis of the person's information at the level of the so-called "main" regulatory or structural genes, which not only take direct part in the formation of economic and useful properties, but also sometimes, in spite of the polygenic nature of the quantitative traits, make a much larger proportion in their manifestation than other genes.

This approach has already proven itself positively in conducting gene selection, aimed at increasing the fattening and meat properties and meat quality, as well as the reproductive characteristics of animals.

In sheep breeding also found genes, with high probability associated with the meat qualities of animals. For example, the gene of myostatin, which affects the development of skeletal muscle; the gene of calpastatin, which has an effect on the meat quality. A gene that is significantly responsible for the 
sheep fattening ability (the factor of differentiated growth of the follicles associated with an increase in the rate of ovulation and infertility) and negative mutations of BMP 15 (bone morphogenetic protein receptor) and Scrapie - spongiform encephalopathy of sheep $[9,10,11,12]$.

Therefore, the concept of further development of research into the use of molecular genetic markers in the sheep breeding selection involves the gradual transition to the widespread use of modern technologies for direct identification of DNA genetic polymorphism in order to create new, more effective methods for assessing genotypes and raising the level of breeding work.

\section{Conclusions}

The scientists of the IABSR "Ascania Nova", as a scientific center for animal breeding in the south of Ukraine, developed a series of selective genetic, technological, biotechnological methods, methodologies, systems for the evaluation and development of animal genotypes. In addition, they created the gene pools of domestic high-productivity, adapted to the extreme natural and climatic conditions of region breeds of sheep and pigs, cattle of dairy and meat productivity directions, which today form the basis of state genetic resources of livestock. Their use contributes to the restoration of certain branches, in particular sheep breeding, and for others to increase the production of high-protein food products, including organic farming.

\section{Bibliography}

1. Yatsenko I.V., Binkevych V.la. (2015). Suchasnyi stan ta tendentsii rozvytku vyrobnytstva produktsii vivcharstva u sviti. [Current state and tendencies of development of production of sheep breeding in the world]. Visnyk Sumskoho natsionalnoho ahrarnoho universytetu. Vyp.1 (36). P. 49-54. [In Ukrainian].

2. Lobachova I.V., Zhulinska O.S., Yakovchuk V.S., Horlova O.D. (2012). Efektyvnist stymuliatsii statevoi okhoty pry ushchilnenni yahnin vivtsematok. [Efficiency of stimulation of sexual hunting during densification of ducks' witches]. Naukovyi visnyk "Askaniia-Nova». Vyp. 5. 4. 1. P. $111-121$. [In Ukrainian].

3. Tkachenko N.A., Skrypnichenko D.M. (2015). Obgruntuvannia parametriv fermentatsii molochnoi osnovy dlia vyrobnytstva miakykh probiotychnykh syriv. [Substantiation of parameters of fermentation of milk basis for production of soft probiotic cheeses]. Naukovyi visnyk LNUVMtaB im. S.Z. Hzhytskoho. No 1(61). P. 107 - 116. [In Ukrainian].

4. Zoria P.S. (2014). Vyrobnytstvo ekolohichno chystoi produktsii: problemy ta vyklyky sohodennia. [Production of environmentally friendly products: challenges and challenges of the present]. Ekonomika $i$ upravlinnia. No 3. P. 45 - 50. [In Ukrainian].

5. Ivanov M.F. (1933). Novaya poroda sviney - ukrainskaya stepnaya belaya, vyvedennaya $v$ Askanii-Nova, i metody ee obrazovaniya. [New breed of pigs - Ukrainian white steppe, bred in AskaniaNova, and methods of its formation]. Moskva. 135 p. [In Russian].

6. Greben' L.K., Greben' E.K. (1961). Ukrainskie stepnye ryabye svin'i. [Ukrainian steppe speckled pigs]. Kiev. 90 p. [In Russian].

7. Dudka O.I. (2012). Osoblyvosti uspadkuvannia produktyvnykh oznak svynei ukrainskoi miasnoi porody. [Features of inheritance of productive features of Ukrainian breed pigs]. Naukovyi visnyk "Askaniia-Nova». N. Kakhovka: PYEL. Vyp. 5. Ch. II . P. 228 - 236. [In Ukrainian].

8. Davis G.H. (2004). Fecundity genes in sheep. Animal Reproduction Science. V. 82 - 83. P. $247-253$.

9. Galloway S.M., Menatty K.P., Cambridge L.M. et al. (2000). Mutations in an oocyte-derived growth factor (BMP15) cause increased ovulation rate and infertility in a dosage-sensitive manner. Nat. Gen. V. 25. P. $279-283$.

10. Anani Azari M., Dehnavi E., Yosefi S., Shahmohamadi L. (2012). Polymorphism of calpastatin, calpain and myostatin genes in native Dalagh sheep in Iran. Slovak J. Anim. Sci. V. 45. No 1. P. $1-6$.

11. Seiler J. (1994). The future role of molecular genetics in the control of meat production and meat quality. Meat Sci. V. 36. P. 29. 